AWEJ for Translation \& Literary Studies, Volume3, Number3. August 2019

DOI: http://dx.doi.org/10.24093/awejtls/vol3no3.16

Pp.198 -210

\title{
The Unavoidable Suffering in Selected Literary Texts: Poems and Novels
}

\author{
Amal Nasser Frag \\ Department of English, College of Education Ibn Rushd \\ University of Baghdad, Baghdad, Iraq
}

\begin{abstract}
The unavoidable suffering is an outstanding theme which has its impact to almost all literary texts. Typically, unavoidable suffering is the supreme touchstone in life and literature. Poets used its presence incessantly. They are always conscious of its inevitability. Investigation of this theme gives the reader a panoramic view of vital issues that are unusually linked to some extent with suffering; such as religion, God, nature, love and immortality. In the poems discussed in this study, unavoidable suffering reflects the effect of modern psychology has had upon both literature and literary criticism. The main reflection of suffering which is implied in the characters presented reveal the very contradictions, absurdities and complexities of our life. The poets and novelists chosen in this paper portray suffering, as "an abstract force, in an attempt to come to terms with it as well as to fathom it." (Gurra, 2019, p.5) In the inexorable quest to comprehend it, poets do not offer a final view of suffering because it remains for them the great unknown mystery. This paper, however, is an attempt to meticulously examine and critically analyze the images of suffering in minor characters presented in selected poems. The selected poems are of Robinson Jeffers, Allen Ginsberg, and Maya Angelou. The characters selected from different novels are minor ones. Characters like: Roger Chiilingworth from The Scarlet Letter (1850), Walter Morel from Sons and Lovers (1913), Zeena Frome from Ethan Frome (1911), and Rezia Warren Smith from Mrs. Dalloway (1925). Different kinds of suffering are disscussed in order to gain a better understanding of the writers' perception of unavoidable suffering as well as to understand the western philosophy of it.
\end{abstract}

Keywords: Allen Ginsberg, Maya Angelou, literary texts, Robinson Jeffer, The Scarlet Letter, Sons and Lovers, Ethan Frome, Mrs. Dalloway, unavoidable suffering

Cites as: Frag, A. N. (2019). The Unavoidable Suffering in Selected Literary Texts: Poems and Novels. Arab World English Journal for Translation \& Literary Studies, 3 (3) 198 -210.

DOI: http://dx.doi.org/10.24093/awejtls/vol3no3.16 


\section{Introduction}

Psychological Criticism as an approach replicates the outcome that modern psychology has had upon both literature and literary criticism. The psychoanalytic theories presented by Sigmund Freud (1856-1939) and Carl Jung (1875-1961) try to explicate the notions of human behavior. They explore new and/or controversial areas like fears, desires, the unconscious, and repression. In the psychological approach, the analysis of fictional characters in literature can be done by the analysis of the use of language, i.e., the words and action that express what is hidden or a secret to other characters in the literary text. They are the analysis of what is lying deep in the poet's or the character's mind and heart. (Strachey, 1961, p.26).

\section{What is Suffering?}

The terminology of the word "suffering", according to Webster Dictionary (1999), is sometimes used in the narrow sense of physical pain, but more often, it refers to "mental or emotional pain, or more frequently yet, to pain in the broad sense, i.e., to any unpleasant feeling, emotion or sensation." (p.828)

The expression pain regularly refers to physical pain, but it is also a common synonym of suffering. Within the same context, Freud defined suffering as how we are threatened with [it] from three directions: from our own body, which is doomed to decay and dissolution and which cannot even do without pain and anxiety as warning signals; from the external world, which may rage against us with overwhelming and merciless forces of destruction; and finally from our relations to other men. The suffering which comes to us from this last source is perhaps more painful to us than any other. (Strachey, p.26)

The final type of suffering is what we call it the unavoidable suffering. It is a condition of existence, a part of the mystery that shrouds everybody's life. It is usually the result of broken attachments to those one loves or the loss of something appreciated. It cannot be prevented because death and perpetual change are uncontrollable of living. (Webster's Collegiate Dictionary, 1999, p.828).

On the other hand, much suffering can be prevented by making wise choices. But there is so much more unavoidable suffering that one refuses to acknowledge as the expected consequence of the natural movement of life or certain situations that one finds himself indulged in, without having any type of escape. Therefore, the poems that present suffering chosen in this paper suffer and live in woe and have to accept their suffering because poor decisions lead to catastrophic outcomes and refusing to accept the inevitable adds much to the pain of life.

\section{Unavoidable Suffering In Selected Poems}

Robinson Jeffers (1887-1962) writes "Hurt Hawks" (1928) in two parts, using the narrative technique. The poem is about a bird, which usually held a special place in the poet's heart. The bird is a wounded hawk in suffering. Jeffers appeals to be compassionate with the hurt Hawk as it lives in and around the poet who marks clearly, however, that the hawk is not a prisoner, in either the poet's eyes or its own. The poem opens: 
The broken pillar of the wing jags from the clotted shoulder, The wing trails like a banner in defeat,

No more to use the sky forever but live with famine

And pain a few days

(Jeffers, 2012, p.198)

It is noted here that animals were very important to Jeffers as noble representatives of the natural world man lives in. Jeffers goes on describing how he takes care of the injured hawk.

We had fed him six weeks, I gave him freedom,

He wandered over the foreland hill and returned in the evening, asking for death,

Not like a beggar, still eyed with the old

Implacable arrogance.

(Jeffers, 2012, p.198)

The poem is reminiscent to compare an injured hawk to the injured spirit of a man who can live in pain and this is clear in saying: "He is strong and pain is worse to the strong, incapacity is worse. / The curs of the day come and torment him / At distance, no one but death the redeemer will humble that head." (Jeffers, 2012, p.199)

The whole poem surfs in suffering, pain, and defeat, yet Jeffers wants to assure his message that God can keep us strong through suffering which is mandatory.

Allen Ginsberg's poem "Howl" sprays the inevitable suffering of "the best minds" right away in the opening lines of the poem when he says:

I saw the best minds of my generation destroyed by

madness, starving hysterical naked,

dragging themselves through the negro streets at dawn

looking for an angry fix

(Ginsberg, 2006, p.134)

The suffering that Ginsberg is referring to is inescapable as he presents it through a long list of the activities in a catalog technique, introducing it with the word "who"

who poverty and tatters and hollow-eyed and high sat

up smoking in the supernatural darkness of

cold-water flats floating across the tops of citiesmplating jazz,

who bared their brains to Heaven under the El and

saw Mohammedan angels staggering on tene-

who passed through universities with radiant cool eyes

who were expelled from the academies for crazy \& 
who cowered in unshaven rooms in underwear, burning

who got busted in their pubic beards returning through

who ate fire in paint hotels or drank turpentine in

............................................;

who chained themselves to subways for the endless

who sank all night in submarine light of Bickford's

(Ginsberg, 2006, p.134)

Moreover, the list continues in a protest yell, a yell for all, corruption, exploitation, capitalism, repression, tyranny, and subjugation, which the best minds of the 50s suffer from, and therefore their suffering come in different forms. Since they are the best minds of their generation, their misery takes the shape of hysteria, alienation, anger, nakedness, desperation, starvation, and defying the mainstream culture by different neurotic activities. Finally, their suffering is rewarded in a transcendental reality, which the poet is looking for as a reward, a goal and destination for all the scholars, best minds, and best generations in their times.

Inescapable suffering in Maya Angelou's poetry touch on topics dealing with the misery and anguish of the African-American people. In her poem "Woman Work" (1978), she summarized the anguish, exploitation, and suffering of the African-American woman who is representative of any woman whose daily life is dedicated to caring for others. She might be a slave or a desperate woman since the poem is written in a critical decade when the manipulation for women is a general remark.

The unavoidable suffering in Angelou's poem starts right away with the introductory lines when the narrator of the poem unveils herself as a woman who is exploited is to work extremely hard for someone else's benefit. The woman talking is with no doubt a slave as the list of her list to do never ends as soon as she finishes the last one the sequence begins again. She is worn, fatigued, and weary.

I've got the children to tend

The clothes to mend

The floor to mop

The food to shop

Then the chicken to fry

Then baby to dry

I got company to feed

The garden to weed

I've got the shirts to press

The tots to dress

Arab World English Journal for Translation \& Literary Studies

ISSN: 2550-1542 | www.awej-tls.org 
The cane to be cut

I gotta clean up this hut

Then see about the sick

And the cotton to pick.

(Angelou, 1994, p.153)

The suffering of the slaves of the African-American becomes an important part in the AfricanAmerican culture. No reader of an African-American poet can overlook that theme and in "Woman Work" it is stated clearly as the woman lives in a hut and she have to pick up thee cotton which are usually the works of the African-American people. Angelou confirms that the AfricanAmerican woman can rejuvenate and has comfort only in the gifts nature has given her that can heal all her wounds.

Shine on me, sunshine

Rain on me, rain

Fall softly, dewdrops

And cool my brow again.

Storm, blow me from here

With your fiercest wind

Let me float across the sky

'Til I can rest again.

Fall gently, snowflakes

Cover me with white

Cold icy kisses and

Let me rest tonight.

Sun, rain, curving sky

Mountain, oceans, leaf and stone

Star shine, moon glow

You're all that I can call my own.

(Angelou, 1994, p.153)

\section{Unavoidable Suffering in Selected Novels}

Nathaniel Hawthorne (1804-1864) was a moralist and psychologist who was concerned not only with the moral implications of sin but also with the effects of that sin on the person who committed it. (Armstrong, 1976, p.103) Thus, sin and its consequences, i.e., suffering became almost the major theme in his novel.

Roger Chillingworth, according to Hawthorne and some critics, has the role of the villian in this story. Although he is originally the only character without a problem or a sin, he becomes the one who "performed the worst sins of all" (Armstrong, 1976, p.103) in the eyes of Hawthorne, 
many critics, and the readers of the novel. In fact, Hester Prynne and Arthur Dimmesdale do both have committed a sin, yet Chillingworth has committed none.

As any man who has found his wife to be adulterous, Chillingworth reacts with a fairly normal response, although angry and wanting revenge, he does not react totally unreasonably. He suffers too as all other characters in the novel do and his suffering is unavoidable due to the accumulation of the agony he feels as he is presented among the throng of people who watch Hester on the scaffold of shame as the crooked husband. (Hawthorne, 1999, p.62)

Chillingworth's character shows some nobility in spite of the fact that Hawthorne tried his best to present him the villian of the novel. He is Hester's husband, who has arrived in Boston almost three years after Hester has come to it. When he finally sees Hester, she is standing on a scaffold in front of him, accused of committing adultery. According to the law, if Chillingworth has chosen to identify himself, Hester will have been sentenced to death. Definitely, that shows some noble feature. After learning this about his wife, Chillingworth still treats Pearl, when she is anguished, even though it is his wife's child by another man. When Hester fears that Chillingworth may have tried to poison Pearl, he responds: "What should ail me to harm this misbegotten and miserable babe?" (Hawthorne, 1999,p.72) That incident adds another nobility to his character. Chillingworth admits that he is partly at fault for her sin, "I have greatly wronged thee." (Hawthorne, 1999,p.74) She is a young woman and he is an old man; he can never expect her to love him. "I drew thee into my heart, into its innermost chamber, and sought to warm thee by the warmth which thy presence made there!" (Hawthorne, 1999, p.74) Chillingworth unfolds the truth about himself as he is an introvert man. "I - a man of thought - the bookworm of great librariesa man already in decay, having given my best years to feed the hungry dream of knowledge ... I came out of the vast and dismal forest and entered this settlement of Christian men; the very first object to meet my eyes would be thyself, Hester Prynne ....” (Hawthorne, 1999, p.74-75)

The reader of the novel can observe and imagine the situation that Chillingworth finds himself in so as to give a fair judgement. He is in a complex situation and he acts neither as a fiend or a villian, but as a human being. Thus, he develops a strong desire to find out with whom his adulterous wife has had an affair and that becomes the quest of his life.

As a man of knowledge, he suspects Dimmesdale's deadly defense on behalf of Hester and her daughter. Thus, he now “dug into the poor clergyman's heart, like a minor searching for gold, or, rather like a sexton delving into a grave, possibly in quest of a jewel that had been buried on the dead man's bosom." (Hawthorne, 1999, p.116) Here, Chillingworth becomes the minor who dig for hidden truths in the clergyman's heart. That is clearly shown in his agitated dancing in discovering and seeing Dimmesdale's imprinted mark on his chest.

In the matters of outside appearance, naming, and clothing. Hawthorne did his best to show the man as an emblem of evil and villainy. His dark clothes, cold name, and the deformity of his physique make the characters in the novel identify Chillingworth with the Black Man. In fact, what 
Hawthorne tried to do was to link Chillingworth with the black image of the Puritan society he presented. (Stubbs, 1986, pp..142-144)

Almost all characters presented in The Scarlet Letter suffer, and Chillingworth is no exception. His suffering is unavoidable and it originates from actually no concrete sin and all his actions are only reactions to the complexities he has found himself in reluctantly. He does deserve the reader's sympathy and honest compassion as he gets his redemption at the end of the novel in making Pearl his heir.

D. H. Lawrence, (1885-1930) later in his life, came to regret the way in which he portrayed Walter Morel; "in his later books," says Alastair Niven: "[Lawrence] came to admire the type of man which he believed his father to have been far more than would appear from his portrait of Walter Morel, who is presented initially as unreasonably ill-tempered, then as weak-willed, and finally as an empty husk from whom the kernel of life has been removed." (Nivan, 1978, p.55) In Sons and Lovers, the reader gains a good understanding of what the character of Walter Morel is like; in certain parts, one can sympathize with Gertrude Morel and understand her struggle and strife, yet there are moments in which, one sees Mr. Morel really a vulnerable and mis-understood character. Thus, one may believe that he is the one, not Mrs. Morel, who deserves the reader's sympathy.

In the very first chapter of the novel, the reader learns about the first meeting between the couple, where Walter first asks for the hand of the would-be his wife; it is here that he gets a brilliantly positive description by Lawrence, Morel is "well set-up, erect, and very smart." (Lawrence, 1981, p.9) He is given a rather attractive description, with black wavy hair and a thick beard. (Lawrence, 1981, p.9) There is also an insight into his character; he laughs a lot during the first meeting, thus suggesting a happy, relaxed figure. He also appears a rather bold and likable character, Gertrude finds herself strangely attracted to. Probably, as Van Ghent points out, to be a very important aspect in Morel's character is his use of dialect, despite she is being described as "opposite" to her new found love. (Lawrence, 1981, p.9)

The calamity of the Morels starts only after the discovery of Walter's lies about owning the house and about the unpaid furniture bills. (Lawrence, 1981, p.12) These lies show the feeling of hiding his shameful poverty from the lady he has just married. He has no hand in belonging to the working class as he works as a miner, and Gertrude, belongs to the middle class, and knows exactly to what class she has married. Her superiority in being of that class drives her to look down upon him and despise him. (Lawrence, 1981, p.14) Lawrence, himself, gives an illuminating remark about the cause of the tragedy of the Morels' marriage: "The pity was, she was too much his opposite. She could not be content with the little he might be; she would have him the much that he ought to be. So, in seeking to make him nobler than he could be, she destroyed him." (Lawrence, 1981, p.16) Thus, Gertrude's marriage to Walter is considered a step down that leads them to live their marital life in bitterness, violence, and hate. 
As a solution to the misfortune she finds herself in, as she is unhappy and disillusioned with the lower-class mining-family lifestyle and is "sick of it," (Lawrence, 1981,p.5) and "the struggle with poverty and ugliness and meanness" chocks her, she shrinks from her marital life and from the contact with the Bottom's women of her neighbourhood, to resolve to stay in her unhappy marriage "and all the time ... thinking how to make the most of what she had, for the children's sake." (Lawrence, 1981, p.6) Thus, instead of trying to refine Mr. Morel and make him nobler, or at least change herself according to her new situation, she becomes indifferent to him and that leads to his pathetic deterioration and his suffering.

The estrangement of Mr. Morel starts after, the discovered lies, with the birth of William, who gives exclusive consolation to Gertrude as she casts away her husband. (Lawrence, 1981, p.45) Mrs. Morel turns away from her husband and invests all her love and energy in her sons, William and Paul. That alienation from the husband leads to his complete deterioration, as he turns to heavy drinking and wastes his evenings at the pub; spending his family's much-needed money; "his pride and moral strength" (Lawrence, 1981, p.26) vanish. As a result, the quarrels start on as she obstinately refuses to serve him, as a good housewife may do, and prefers waiting on a dog, instead; "never, milord. I'd wait on a dog at the door first." (Lawrence, 1981, p.38) Such a kind of treatment makes Mr. Morel suffer, as Lawrence beautifully describes him: "Walter Morel lay in bed next day until nearly dinner-time... He lay and suffered like a sulking dog. He had hurt himself most; and he was the more damaged because he would never say a word to her, or express his sorrow." (Lawrence, 1981, p.40-41)

In all these incidents, what really irritates the reader is that not only does Mrs. Morel degrade and look down upon her husband, but also transfers this disdain and hate to the children, leading them to view life through her own eyes and perspective. That leads Mr. Morel into complete loneliness, as at the moment he enters the house, the children are hushed to silence, and he is completely shut out from all the family affairs. No one spoke to him; "the family life withdrew, shrank away, and became hushed as he entered. But he cared no longer about his alienation." (Lawrence, 1981, p.42)

Mr. Morel may be rough and unrefined in his manner, but he is essentially noble at heart. His repentance after each confrontation with his wife and feeling sorry to hurt her is really genuine, and deserves to be respected. (Lawrence, 1981, p. 45) He has also a real love for his children, but they, under the influence of their mother, never respond to it. He is driven away further and further from his children, to the point where he is "hated" by them all; "William ... hated him, with a boy's hatred for false sentiment, and for the stupid treatment of his mother. Annie had never liked him; she merely avoided him." (Lawrence, 1981, p. 35) As for Paul, his hatred is of another intense kind; "Paul hated his father. As a boy he had a fervent private religion," he prays God every night, asking to "make him stop drinking," and implores: "Lord, let my father die." (Lawrence, 1981, p. 60) Morel does deserve sympathy for the love he holds for his children, but they never feel it because their hatred to him is rooted deep in their hearts and is grown with them. Long after William's death, Walter never is able to pass near the cemetery where he is buried, or near the office where he worked. (Lawrence, 1981, p.141) When William dies, he is brought home to be 
buried by his mother and not father. (Lawrence, 1981, p.141) He feels quite concerned when someone in the family gets ill, but they are highly indifferent to him.

Mr. Morel suffers and his suffering is unavoidable as the love and devotion he has for Gertrude and their children is intense but he loses the battle with his most articulated and educated wife. So, the reader's sympathy and consciousness may go to Mr. Morel's side as his loneliness reaches the highest point with the family's increasing hostility.

It is not stange, then, to accept the truth of Lawrence's claim, in later life, saying: "It would write a different Sons and Lovers now; my mother was wrong, and I thought she was absolutely right." (Lawrence, 1934, p.74) Thus, if the mother is completely wrong, in the new version of Sons and Lovers, he might have given true and fair credit to Mr. Morel.

In Edith Wharton's Ethan Frome (1911), Zeena, Ethan's wife, plays an important role in the novel. Zeena suffers and her suffering is inevitable as she is entrapped in the marrage to Ethan. Wharton portarays Zeena as one of the most unappealing character one can ever imagine. She is presented as the unhappy ailing wife. She is thirty-five at the time the events of the novel take place. (Wharton, 1988, p. 35) She rarely opens her mouth, except to complain or criticize. She doesnot need words to tell one what she thinks of because on her face is "a constant disapproval" (Wharton, 1988, p. 35) Zeena is mean and heartless in the eyes of Ethan, Mattie, and myabe Wharton herself. Yet, she is more human than other characters. She does have certain good qualities if she can be seen in fair and just eyes, and not of Ethan's or Mattie's.

Zeena comes to the Frome's house with good intentions, so as to help her cousin, Ethan, nursering his ailing mother. (Wharton, 1988, p. xii) She does her job perfectly and with the mother's death, she is ssen by Ethan "preparing to go away" (Wharton, 1988, p. 40) In an act of complete selfishness, Ethan thinks of himself and how the life of silence will be unbearable as he is "seized with an unreasoning dread of being left alone.... He ask[s] her to stay there with him." (Wharton, 1988, p. 40)

As it is presented, it seems the whole act of the proposal of marraiage is an act of complete selfishness on the part of Ethan. Yet, on the part of Zeena, it is deep and sincere love as she feels it is her duty to rescue her cousin from his distress by wedding him and helping him to get his life fixed. (Wharton, 1988, p. 40) All she wants from Ethan is to return her love and devotion. When she realizes that this love is unattainable, bitterness fills up the space where love exists.

Zeena turns out to be hypochondrial, i.e., she thinks herself sick because of "the inevitable effect of life on the farm" (Wharton, 1988, p. 41). Her sickness increased because Ethan "never listen[s]" to her.and he "look[s] at her with loathing." She feels she is no longer "the listless creature who had lived at his side in a state of sullen self-absorption, but a mysterious alien presence, an evil energy secreted from the long years of silent brooding (Wharton, 1988, p. 67) He ignores her presence completely, and when she talks he forms a habit of "not answering her, and finally of thinking of other things while she talked." (Wharton, 1988, p. 31) 
Ethan's negligence of Zeena makes her fully "absorbed in her health." (Ethan From, 34) $\mathrm{He}$ is the reason behind her poor health as he never "exchanged a word after the door of their room had closed on them." (Wharton, 1988,p.31) He usually blows out "the light [hurriedly] so that he should not see her when he took his place at her side." (Wharton, 1988, p. 31) So, It is Ethan's fault and not Zeena's as he is "by nature grave and inarticulate." (Wharton, 1988, p. 39) $\mathrm{He}$ is paasive and futile as he lives in a daydreaming world even when goes for a night outdoors leaving Ethan and Mattie alone for a whole night; he does not even try to touch Mattie's hands but "set his imagination adrift on the fiction that they had always spent their evenings thus and would always go on doing so." (Wharton, 1988, p. 51) All he can do is to touch the farther end of the strip of brown stuff that she was hemming." (Wharton, 1988, p.51) On the following day, he feels "glad ... that he had done nothing to trouble the sweetness of the picture." (Wharton, 1988, p.55) He is a weak and negative person who leads Zeena to turn her face away from him when she takes her place in the bed. (Wharton, 1988, p.31) He is inactive and submissive as even the suicide attempt is not his idea but Mattie's. (Wharton, 1988, p.91)

However, Zeena is still able to think of others, like Mattie. Mattie, that orphan gile who has has no father or mother and has been left alone without home or money. (Wharton, 1988, p. xii) Zeena takes her in, out of charity, to help around the house. (Wharton, 1988, p. xii) The first day Mattie comes, she is " a coloeless slip of a thing." (Wharton, 1988, p. 31) Yet, under the roof of Zeena, Mattie is able to blossom and her face becomes "part of the sun's red and of the pure glitter on the snow." (Wharton, 1988, p.31)

Zeena is the one who loves Ethan, the one who has taken care of his mother and Mattie comes to enchant him with her youthful energy; he falls immediately in love with her. When Mattie achieves the one thing that Zeena never can do (to fall in love with Ethan), the hurt overwhelms her and therefore decides to banish Mattie from her home by sending her away. (Wharton, 1988, p.66) However, when the horrible accident occurs, Zeena rises from her sickbed and never return to it to take care for the next twenty four years of the woman who has tried to steal her husband. (Wharton, 1988, p.100)

Mrs. Hale admits that "nobody knows Zeena's thoughts ... when she heard o' the accident she came right in and stayed with Ethan .... And as soon as the doctors said that Mattie could be moved, Zeenaa sent for her and took her back to the farm." (Wharton, 1988, p. 99) Wharton might say that Zeena does that out of ultimate revenge by looking after her rival, but Zeena might say that it is her kind heart and her true humanitarian nature impel to take care of others in need.

Suffering takes many forms in Woolf's Mrs. Dalloway, and one of its forms is Rezia. Razia suffers and her suffering is unavoidable as the agony she feels in her marital life is inexplicable. Rezia's suffering comes from her empathy for her husband and a deep sense of isolation from her sweet home, Italy.

In Virginia Woolf's novel Mrs. Dalloway (1925), Rezia or Lucrezia Warren Smith is that "little woman, with large eyes in a sallow pointed face; an Italian girl." (Woolf, 1976, p.15) She is 
Septimus' wife, whom he has met at the end of the war when he has been staying at her home in Milan, Italy. In Italy, she has been a hat maker with her sisters and loved her life.

Rezia is a unique character in the way she knows and acknowledges her suffering and the wickedness of life as she often repeats to herself: "Why should I suffer? .... Why should ... suffer? .... Why tortured? Why?" (Woolf, 1976, p.59) But really why, one may chew on this question; why does she suffer? The moment the reader is introduced to her husband, Septimus, one feels that there is something wrong with him; he is " aged about thirty, pale-faced, beak-nosed, wearing brown shoes and a shabby overcoat, with hazel eyes which had that look of apprehension in them which makes complete strangers apprehensive too." (Woolf, 1976, p.15) To him; "the world has raised its whip; where will it descend?" (Woolf, 1976, p.15)

Thus, she endures living with a veteran suffering severe bout of mental illness who has visions of his dead comrade Evans and other hallucinations like: "see[ing] a dog became a man! At once the dog trotted away," (Woolf, 1976, p.61) or seeing "faces laughing at him, calling him horrible disgusting names, from the walls and hands pointing round the screen," (Woolf, 1976, p. 60) or "answering people, arguing, laughing, [and] crying." (Woolf, 1976, p. 61) She tolerates his agony, hoping that he will one day recover, as that is asserted by Septimus's psychiatrist, Dr. Holmes who affirms that "there was nothing the matter with him." (Woolf, 1976, p. 61) She bears her husband, because she has left everything behind her, in Italy as she likes the idea of being wedded to an Englishman because they are "so serious." (Woolf, 1976, p. 80) In addition, "the English are so silent, she liked it.... She respected these Englishmen, and wanted to see London, and the English horses, and the tailor-made suits, and could remember hearing how wonderful the shops were, from an Aunt who had married and lived in Soho." (Woolf, 1976, p.79)

In London, Rezia feels extremely isolated. Not only is the culture dramatically different, but she also really suffers from Septimus' mental illness. She makes every effort to help him heal, but she knows that the doctors lack the kind of care he needs. Septimus is too far gone to really be concerned with his wife. He cannot understand the fact that his sickness causes her to suffer, too. Her suffering is, of course, just another sign that everyone is affected by the trauma of the war, not just those fighting in it. Her feeling of anguish makes her grow skinny and can endure her marriage no more: "Look! Her wedding ring slipped - she had grown so thin. It was she who suffered - but she had nobody to tell." (Woolf, 1976, p.22)

Rezia suffers because she is actually a foreigner, in terms of social conformity. Rezia suffers from the lack of communication. She comes from Italy, Milan and that place has deep meanings to her: lively places full of nature and intimate female relationships, where they are free to explore ideas and express opinions. She used to live with her sisters making hats and exchanging chats and giggles. However, it is far. Far was Italy and the white houses and the room where her sisters sat making hats, and the streets crowded every evening with people walking, laughing out loud, not half alive like people here, huddled up in Bath chairs, looking at a few ugly flowers stuck in pots!" (Woolf, 1976, p. 22-23) 
Rezia misses all these things and she is homesick for family and country, but she endures her lonely life patiently as a good wife may bear the difficult and bad times. She always cries to herself: "I am a lone; I am alone!" (Woolf, 1976, p.23) She has no one to turn to. Her sisters are in Milan and she feels that London is a cold and unfriendly place. In spite of her loneliness, Rezia makes futile efforts to comprehend and treat Septimus's illness. She helps her husband getting better by following Dr. Holmes's instructions, making and imploring her husband to be engaged to the world which he has isolated himself from. 'Look, look,' Septimus! she cried. For Dr. Holmes had told her to make her husband (who had nothing whatever seriously the matter with him but was a little out of sorts) take an interest in things outside himself.' (Woolf, 1976, p. 21)

Although Rezia, tries desperately to help her husband, she, too, longs for everything to be normal. What she wants is a normal marriage with children, not a man who talks to himself and slips gradually into insanity. She often asks him of having "a boy", "a son" (Woolf, 1976, p.80) to fill her empty world. Yet, Septimus refuses; claiming: One cannot bring children into a world like this. One cannot perpetuate suffering, or increase the breed of these lustful animals, who have no lasting emotions, but only whims and vanities, eddying them now this way, now that." (Woolf, 1976, p.80)

Therefore, She will never have children, because that means bringing more suffering and misery into the world. She cries, for she is so unhappy. (Woolf, 1976, p.64) In spite of her misery, Rezia still feels pity for other people and is sorry for the poor singing woman: Poor old woman. Oh poor old wretch! Suppose it was a wet night? Suppose one's father, or somebody who had known one in better days had happened to pass, and saw one standing there in the gutter? And where did she sleep at night? (Woolf, 1976, p.74) Although Rezia feels miserable and un happy, the scene of the poor woman makes her relieved and somehow hopeful and made her suddenly quite sure that everything was going to be right. They were going to Sir William Bradshaw; she thought his name sounded nice; he would cure Septimus at once. And then there was a brewer's cart, and the grey horses had upright bristles of straw in their tails; there were newspaper placards. It was a silly, silly dream, being unhappy. (Woolf, 1976, p.75)

However, there's definitely one question that Woolf doesn't answer, what Rezia will do after Septimus commits suicide. She may return to Italy. Or, she may stay in London or, she may even suffer more.

\section{Conclusion}

In final words, there is a lot of suffering all over the world. If one happens to pay attention to droughts, violence, and poverty just seem to keep on hitting many countries all over the world. When it comes to suffering, it is unavoidable but leads one to appreciate life one's better.

\section{About the Autor:}

Dr. Amal Nasser Frag, is an assistant professor at the University of Baghdad, College of Education Ibn Rushd- Department of English. She has been teaching poetry and novel for more than 15 years. She also teaches the $19^{\text {th }}$ century American Literature to MA students. ORCiDID: https://orcid.org/0000-0003-2037-1039 


\section{References}

Armstrong, J. (1976) The Novel of Adultery. London: The Macmilian Press Ltd., Angelou, M. (1994). The Collected Poems of Maya Angelou. New York: Random House Publication.

Ginsberg, A. (2006) Collected Poems 1947-1997 of Allen Ginsberg. New York: Harper Collins Publishing. Gurra, H. (2019) "Comparative Analysis of Social Poetries of Emily Dickinson and Migjeni." In ORCID ID http://orcid.org/0000-0002-2358-1210.

Hawthorne, N. (1999) The Scarlet Letter. Oxford: Oxford University Press.

Jeffers, R. (2012). The Selected Poetry of Robinson Jeffers. New York: Random House. Lawrence, D. H. (1981) Sons and Lovers.London: Penguin Books. Lawrence, D. H., Frieda. (1934) Not I, But the Wind. London: Viking Press.

Nivan,A. (1978) D.H.Lawrence:The Novels.Cambridge:Cambridge university Press.

Merriam-Webster's Collegiate Dictionary. (10th ed.) (1999). Springfield, MA: MerriamWebster Incorporated.

Strachey, J. (1961). From Civilization and Its Discontents by Sigmund Freud 1930. New York: Norton Publishers.

Stubbs, J. C. (1986) "Hawthorne's The Scarlet Letter: The Theory of Romance and the Use of New- England Situation," in PMLA 83.

Wharton, E. (1988) Ethan Frome. Minnesota: EMC Corporation.

Woolf, V. (1976) Mrs. Dalloway. London: Granada Publishing Limited.

Arab World English Journal for Translation \& Literary Studies 